\title{
Preemergent Control of Medusahead on California Annual Rangelands With Aminopyralid
}

\author{
Guy B. Kyser, ${ }^{1}$ Vanelle F. Peterson, ${ }^{2}$ Josh S. Davy, ${ }^{3}$ and Joseph M. DiTomaso ${ }^{4}$ \\ Authors are ${ }^{1}$ Specialist and ${ }^{4}$ Cooperative Extension Specialist, Department of Plant Sciences, University of California, Davis, CA 95616, USA; \\ ${ }^{2}$ Senior Scientist, Dow AgroSciences LLC, Mulino, OR 97402, USA; and ${ }^{3}$ Cooperative Extension Farm Advisor, Tehama, Glenn, and Colusa Counties, \\ Red Bluff, CA 96080, USA.
}

\begin{abstract}
Medusahead (Taeniatherum caput-medusae [L.] Nevski), the most problematic invasive grass on many California rangelands, is difficult to control selectively in grasslands. Prescribed burning, grazing, and herbicides have been tested with some success but are not practical in all situations. The selective herbicide aminopyralid, normally used for control of certain broadleaf species such as thistles, suppresses some annual grasses when applied pre- or early postemergence. In 2009-2010, we tested the efficacy of aminopyralid for medusahead control in preemergence applications at three foothill rangeland sites in northern California. We compared a rate series of aminopyralid $\left(53,88,123\right.$, and $245 \mathrm{~g} \cdot \mathrm{ha}^{-1}$ acid equivalent [ae]) with rimsulfuron (18 and 35 $\mathrm{g} \cdot \mathrm{ha}^{-1}$ active ingredient) and imazapic $\left(140 \mathrm{~g} \cdot \mathrm{ha}^{-1} \mathrm{ae}\right)$. Plots were $3 \times 9 \mathrm{~m}$ with four replications at each site. Treatments were applied in early fall 2009. In May 2010, we took visual cover estimates and biomass/seedhead samples in three quadrats per plot. In regression analysis, medusahead cover was found to decrease consistently with increasing rates of aminopyralid. Medusahead control at the highest rates of aminopyralid was consistent across the three sites, averaging $89 \% \pm 3$ standard deviation (SD) with $245 \mathrm{~g} \cdot \mathrm{ha}^{-1}$ ae and $59 \% \pm 10 \mathrm{SD}$ with $123 \mathrm{~g} \cdot \mathrm{ha}^{-1}$ ae. Aminopyralid at lower rates, rimsulfuron, and imazapic were less consistent. Cover of other annual grasses increased in plots treated with aminopyralid at all sites. Aminopyralid has potential utility for suppressing medusahead, particularly in sites also infested with invasive members of the Asteraceae. However, the most effective rate $\left(245 \mathrm{~g} \cdot \mathrm{ha}^{-1} \mathrm{ae}\right)$ is registered for use only as a spot application. In situations where this rate can be justifiably used, it would be expected to give season-long control of medusahead, as well as longer-term control of thistles and other susceptible species.
\end{abstract}

\section{Resumen}

Medusahead (Taeniatherum caput-medusae [L.] Nevski), la especie de pasto invasiva más problemática en muchas áreas de California, es difícil de controlar selectivamente en los pastizales. Se ha probado el fuego prescrito, el pastoreo, y los herbicidas con algo de éxito pero no son prácticos en todas las situaciones. El herbicida selectivo aminopyralid, normalmente usado para el control de ciertas especies de hoja ancha como cardo, suprime algunos pastos anuales cuando se aplica durante la etapa de pre o al inicio de pos-emergencia. In 2009-2010 se evaluó la eficiencia de aminopyralid para controlar medusahead en aplicaciones pre-emergentes en tres sitios localizados en pastizales del norte de California. Se compararon una serie de rangos de aplicación de aminopyralid (53, 88, 123, y $245 \mathrm{~g} \cdot \mathrm{ha}^{-1}$ acido equivalente [ae]) con rimsulfuron (18 y $35 \mathrm{~g} \cdot \mathrm{ha}^{-1}$ de ingrediente activo) e imazapic (140 g. ha ${ }^{-1}$ ae). Las parcelas fueron de $3 \mathrm{~m}$ por $9 \mathrm{~m}$ con cuatro repeticiones en cada sitio. Los tratamientos se aplicaron durante el inicio del verano de 2009. En mayo de 2010 se tomo una estimación visual de la cobertura y muestras de biomasa/inflorescencia en tres cuadrantes por parcela. En los estudios de regresión encontramos que la obertura de medussahead disminuyó consistentemente con el incremento en el rango de aplicación de aminopyralid. El control de medusahead bajo los niveles más elevados de aminopyralid fue consistente en los tres sitios, promediando $89 \% \pm 3 \mathrm{SD}$ con $245 \mathrm{~g} \cdot \mathrm{ha}^{-1}$ ae y $59 \% \pm 10 \mathrm{SD}$ con $123 \mathrm{~g} \cdot \mathrm{ha}^{-1}$ ae. La aplicación de aminopyralid a bajos niveles, rimsulfuron, e imazapic fueron menos consistentes. La cobertura de otras especies de pastos anuales se incrementó en las parcelas tratadas con aminopyralid en todos los sitios. Aminopyralid tiene un potencial para suprimir medusahead, particularmente en sitios infestados con los miembros invasivos de asterácea. Sin embargo, la tasa más efectiva $\left(245 \mathrm{~g} \cdot \mathrm{ha}^{-1}\right.$ ae) está documentada para uso solo de aplicación a un sitio específico. En situaciones donde esta tasa puede ser usada justificadamente, se esperaría que ofreciera control durante toda la temporada sobre medusahead así como control a largo plazo de cardos y algunas especies perenes.

Key Words: chemical, invasive, rangeland, selective, Taeniatherum caput-medusae, weed

\section{INTRODUCTION}

Medusahead (Taeniatherum caput-medusae [L.] Nevski), a Mediterranean winter annual, is the most problematic invasive

This research was funded in part by Dow AgroSciences.

Correspondence: Guy B. Kyser, Dept of Plant Sciences, Mail Stop 4, University of California, 1 Shields Ave, Davis, CA 95616, USA. Email: gbkyser@ucdavis.edu

Manuscript received 7 January 2012; manuscript accepted 31 March 2012. grass on many California rangelands. It is estimated to infest over 950000 ha (2.4 million acres) in the 17 western states (Duncan and Clark 2005). Medusahead foliage has a high silica content, which discourages grazing and retards decomposition, often resulting in a persistent thatch that suppresses germination and establishment of other rangeland species (Bovey et al. 1961). As a result of this thatch and grazing selectivity, medusahead infestations can develop into nearmonotypic stands, which can reduce grazing capacity on 
rangelands by as much as $80 \%$ (Hironaka 1961; George 1994). Furthermore, medusahead seeds have sharp, silicarich, barbed awns, which discourage seed predation and can injure grazing animals.

It can be difficult to selectively remove an invasive grass such as medusahead from a grassland community. In productive, low-elevation grasslands, medusahead can be controlled with prescribed burning in late spring, before its seeds ripen (Kyser et al. 2008). At this timing, most desirable species have already dropped their seed to the soil surface where temperatures from a grass fire are not lethal (DiTomaso et al. 1999a; Sweet et al. 2008). However, this technique is less effective in low productivity, high-elevation sites (Young et al. 1972). In addition, burning is not always an option due to concerns over containment and air quality. Alternatively, medusahead can be suppressed with intensive grazing just prior to heading (DiTomaso et al. 2008), but this technique is difficult to scale up because it requires a large number of animal units in a short time window. Researchers in California and elsewhere have used imazapic for control of medusahead (Shinn and Thill 2002; Monaco et al. 2005; Sheley et al. 2007), but this chemical has limited selectivity, gives variable results depending on soil texture, and tends to become tied up in thatch (Kyser et al. 2007).

Aminopyralid is a synthetic auxin herbicide that was registered for use in rangeland and noncrop areas in 2005 (Carrithers et al. 2005). In California, it is most widely used for pre- and postemergence control of yellow starthistle (Centaurea solstitialis L.). In other states, it has been very effective for the management of Canada thistle (Cirsium arvense [L.] Scop.; Enloe et al. 2007), Russian knapweed (Acroptilon repens [L.] DC.; Enloe et al. 2008), orange hawkweed (Hieracium aurantiacum L.; Seefeldt and Conn 2011), and tropical soda apple (Solanum viarum Dunal; Ferrell et al. 2006).

Aminopyralid is broadleaf-selective and has generally proved very safe on established grasses. However, we have observed under field conditions that aminopyralid can have a negative impact on annual grasses when applied preemergence or early postemergence. This effect is species-specific and includes suppression of soft brome (Bromus hordeaceus L.), cheatgrass (Bromus tectorum L.), and medusahead. Other researchers have reported using aminopyralid for control of hare barley (Hordeum murinum L.; Hulting et al. 2012) and for suppressing seed production in Japanese brome (Bromus japonicus Thunb. ex Murr.; Rinella et al. 2010). In a preliminary study, we tested several rates of aminopyralid on medusahead both pre- and postemergence in a replicated trial in the greenhouse. Treated pots had significantly reduced plant vigor, with a greater effect in pots treated preemergence; preemergence-treated pots also had reduced seedling emergence (Kyser and DiTomaso, unpublished data, 2009). Based on these results, we chose to test aminopyralid in preemergence applications in the field.

The objectives of this study were to determine the susceptibility of medusahead to preemergence applications of aminopyralid under California foothill rangeland conditions and to evaluate the effect of these applications on desirable forage species.

\section{METHODS}

\section{Study Sites}

We conducted this study at three locations in low-elevation foothills of the northern Central Valley of California. All locations were in previously grazed annual grassland within blue oak (Quercus douglasii Hook. \& Arn.) woodland. All sites were fenced to exclude livestock. The southernmost site was at Bobcat Ranch, near Winters, Yolo County (lat $38^{\circ} 31^{\prime} \mathrm{N}$, long $122^{\circ} 02^{\prime} \mathrm{W}, 91-\mathrm{m}$ elevation). The soil was Corning gravelly loam (Typic Palexeralfs), with $0.5-1 \%$ organic matter in the top 30 $\mathrm{cm}$ (USDA-NRCS 2011). A second site was at the University of California Sierra Foothills Research and Extension Center near Marysville, Yuba County (lat $39^{\circ} 15^{\prime} \mathrm{N}$, long $121^{\circ} 17^{\prime} \mathrm{W}, 260-\mathrm{m}$ elevation). The soil was Auburn-Timbuctoo-Argonaut gravelly loam (Lithic Haploxerepts, Typic Rhodoxeralfs, and Mollic Haploxeralfs, respectively) with $0.5-2 \%$ organic matter. The northernmost site was at Gallatin Ranch near Red Bluff, Tehama County (lat $40^{\circ} 04^{\prime} \mathrm{N}$, long $122^{\circ} 24^{\prime} \mathrm{W}, 165$-m elevation). The soil was Tehama loam (Typic Haploxeralfs) with $0.5-3 \%$ organic matter.

\section{Treatments}

We compared a series of four rates $(53,88,123$, and 245 $\mathrm{g} \cdot \mathrm{ha}^{-1}$ ) of aminopyralid (Milestone $\left[2 \mathrm{lb} \cdot \mathrm{gal}^{-1}\right.$ acid equivalent $\{\mathrm{ae}\}$, Dow AgroSciences LLC, Indianapolis, IN) with two rates (18 and $35 \mathrm{~g} \cdot \mathrm{ha}^{-1}$ active ingredient [ai]) of rimsulfuron (Matrix [25\% ai], DuPont Crop Protection, Wilmington, DE) and one rate $\left(140 \mathrm{~g} \cdot \mathrm{ha}^{-1} \mathrm{ae}\right)$ of imazapic (Plateau [2 lb $\mathrm{gal}^{-1}$ ae], BASF Corporation, Research Triangle Park, NC). The four rates of aminopyralid ranged from the lowest labeled rate to the highest labeled broadcast rate, as well as a higher rate labeled only for spot spraying $\left(245 \mathrm{~g} \cdot \mathrm{ha}^{-1}\right)$. A preliminary trial in the greenhouse indicated that medusahead was highly sensitive to rimsulfuron, so we tested this treatment at one-quarter and one-half the maximum label rate. Previous studies have shown that imazapic ties up in thatch, necessitating the use of higher rates (Kyser et al. 2007), so we used a relatively high rate of this chemical. Untreated controls were also included at each site.

At each site, treatments were arranged in randomized complete blocks with four replications. Plots were $3 \times 9 \mathrm{~m}$. Treatments were applied using a $\mathrm{CO}_{2}$ backpack sprayer at 207 $\mathrm{kPa}\left(30 \mathrm{lb} \cdot \mathrm{in}^{-2}\right)$ and $3-\mathrm{m}$ spray boom with six 8002 nozzles. The spray volume was $187 \mathrm{~L} \cdot \mathrm{ha}^{-1}\left(20 \mathrm{gal} \cdot \mathrm{acre}^{-1}\right)$. Treatments were applied 28 September (Red Bluff), 8 October (Marysville), and 9 October 2009 (Winters). At all sites, only minor precipitation $(<9 \mathrm{~mm})$ occurred prior to treatment, and neither medusahead nor other annual species had emerged. The first major precipitation event of the season occurred after the applications (12-15 October), with $>5 \mathrm{~cm}$ of rainfall at all sites. Emergence of grass seedlings occurred following this rainfall event. Over the succeeding rainy season (through 30 June 2010), all sites received between $82 \%$ and $119 \%$ of average rainfall: $69 \mathrm{~cm}$ in Winters (30-yr mean $=58 \mathrm{~cm}), 65 \mathrm{~cm}$ in Marysville (mean $=79 \mathrm{~cm}$ ), and $61 \mathrm{~cm}$ in Red Bluff (mean $=60 \mathrm{~cm}$; University of California, Integrated Pest Management 2010). 
Table 1. Species recorded prior to treatments in quadrats at each site. Dominant species (consistently present at $>5 \%$ cover) are indicated with an asterisk. Native species are indicated in bold.

\begin{tabular}{|c|c|c|c|c|}
\hline Site & Scientific name of Poaceae species & Common name & Scientific name (Broadleaf family) & Common name \\
\hline \multirow[t]{9}{*}{ Winters } & Aegilops triuncialis L. & Barb goatgrass & *Hypochaeris glabra L. (Asteraceae) & Smooth catsear \\
\hline & *Avena barbata Pott ex Link & Slender oat & Trifolium hirtum All. (Fabaceae) & Rose clover \\
\hline & *Bromus hordeaceus L. & Soft brome & & \\
\hline & Bromus madritensis L. & Foxtail brome & & \\
\hline & Gastridium phleoides (Nees \& Meyen) C.E. Hubb. & Nitgrass & & \\
\hline & Hordeum murinum L. & Mouse barley & & \\
\hline & *Lolium perenne L. subsp. multiflorum (Lam.) Husnot & Italian ryegrass & & \\
\hline & *Taeniatherum caput-medusae & Medusahead & & \\
\hline & *Vulpia myuros (L.) C.C. Gmel. & Rattail fescue & & \\
\hline \multirow[t]{8}{*}{ Marysville } & A. barbata & Slender oat & ${ }^{\star}$ Carduus pycnocephalus L. (Asteraceae) & Italian thistle \\
\hline & *Bromus diandrus Roth. & Ripgut brome & Daucus pusillus Michx. (Apiaceae) & Southwestern carrot \\
\hline & B. hordeaceus & Soft brome & & \\
\hline & B. madritensis & Foxtail brome & & \\
\hline & H. murinum & Mouse barley & & \\
\hline & ${ }^{\star}$ L. perenne subsp. multiflorum & Italian ryegrass & & \\
\hline & ${ }^{\star}$ T. caput-medusae & Medusahead & & \\
\hline & V. myuros & Rattail fescue & & \\
\hline \multirow[t]{8}{*}{ Red Bluff } & A. barbata & Slender oat & *Centaurea solstitialis (Asteraceae) & Yellow starthistle \\
\hline & B. diandrus & Ripgut brome & H. glabra (Asteraceae) & Smooth catsear \\
\hline & ${ }^{\star} B$. hordeaceus & Soft brome & $\begin{array}{l}\text { Amsinckia intermedia Fisch. \& C.A. Mey. } \\
\text { (Boraginaceae) }\end{array}$ & Coast fiddleneck \\
\hline & B. madritensis & Foxtail brome & Medicago polymorpha L. (Fabaceae) & California burclover \\
\hline & ${ }^{\star} H$. murinum & Mouse barley & T. hirtum (Fabaceae) & Rose clover \\
\hline & ${ }^{*}$ L. perenne subsp. multiflorum & Italian ryegrass & & \\
\hline & ${ }^{\star} T$. caput-medusae & Medusahead & & \\
\hline & ${ }^{\star} V$. myuros & Rattail fescue & & \\
\hline
\end{tabular}

\section{Data Collection}

We performed vegetation cover evaluations and biomass sampling in late May of 2010, when medusahead was beginning to flower. Three $1-\mathrm{m}^{2}$ quadrats were randomly thrown in each plot, where cover of each plant species was visually evaluated (to the nearest $1 \%$ for cover $\leq 5 \%$ and to the nearest $5 \%$ for cover $>5 \%$ ) and average height of medusahead was recorded. Three $0.25-\mathrm{m}^{2}$ quadrats were randomly thrown in each plot, and all biomass was clipped at $7.5 \mathrm{~cm}$ above the ground (above the thatch layer), bagged, and dried at $60^{\circ} \mathrm{C}$ for $1 \mathrm{wk}$ before weighing. Results from the three cover quadrats and the three biomass quadrats were averaged for each plot.

In mid-June, we collected 10 medusahead seedheads at random (seedhead closest to toe of shoe at each step) in each plot to evaluate for seed production, seed fill, and germinability. The total number of filled and unfilled seeds was counted for each set of 10 heads. We took 50 filled seeds from each sample, cut off the awns, placed the seeds on blotting paper in 9-cm Petri dishes (one dish for each plot), moistened with $5.5 \mathrm{~mL}$ dionized water, and stored at ambient temperature. Germinating seeds (determined by an emerged radical $>2 \mathrm{~mm}$ ) were periodically counted and removed. Counting was terminated when at least $3 \mathrm{~d}$ had elapsed with no further germination, which occurred within 2 wk for all samples.

\section{Analysis}

Within each site, we performed regression analysis on cover of medusahead, other annual grasses, and broadleaf plants over all rates of aminopyralid, including untreated $\left(0 \mathrm{~g} \cdot \mathrm{ha}^{-1} \mathrm{ae}\right)$. We also performed regressions on indexed cover values ( $\%$ cover relative to untreated plots), combined over all sites.

In order to make comparisons with the other treatments, we performed multiple comparisons on these effects using one-way blocked analysis of variance (ANOVA) with treatment as a fixed effect. Likewise, we compared medusahead height, seeds per seedhead, percent filled seeds, and percent germination of filled seeds, as well as total biomass, using ANOVA. All analyses were performed using JMP 8.0 (SAS Institute 2008). In all cases, at least two out of four variance tests found that variances met ANOVA assumptions for homoscedasticity. Means were separated with the Tukey-Kramer Honestly Significant Difference test $(\alpha=0.05)$.

To compare medusahead control at all sites, we calculated a control index for medusahead cover in each plot at each site, i.e., cover in each plot was divided by the overall mean cover in untreated plots at each site, and the result was subtracted from 100 to give percent control. Control index values were compared using two-factor ANOVA with treatment as a fixed factor and site as a random factor, followed by multiple comparisons. This approach was intended to remove the effects of different baseline medusahead populations among sites. 
Table 2. Results of regression analysis over all rates of aminopyralid for vegetative cover of medusahead, other annual grasses, and broadleaf plants at all three sites. Additional regressions were performed for indexed cover of medusahead (\% cover relative to untreated plots) combined over all sites; for indexed cover of broadleaf plants combined over all sites; and indexed cover of other annual grasses combined for Winters and Red Bluff. (The annual grass population at Marysville was too low to permit combining with other sites.) Data were fitted to polynomial (quadratic) equations, cover $=y_{0}+a \cdot$ rate $+b \cdot(\text { rate }-5.8)^{2}$. The strength of each regression is indicated ("Prob $>F$ "). ND indicates analysis not done.

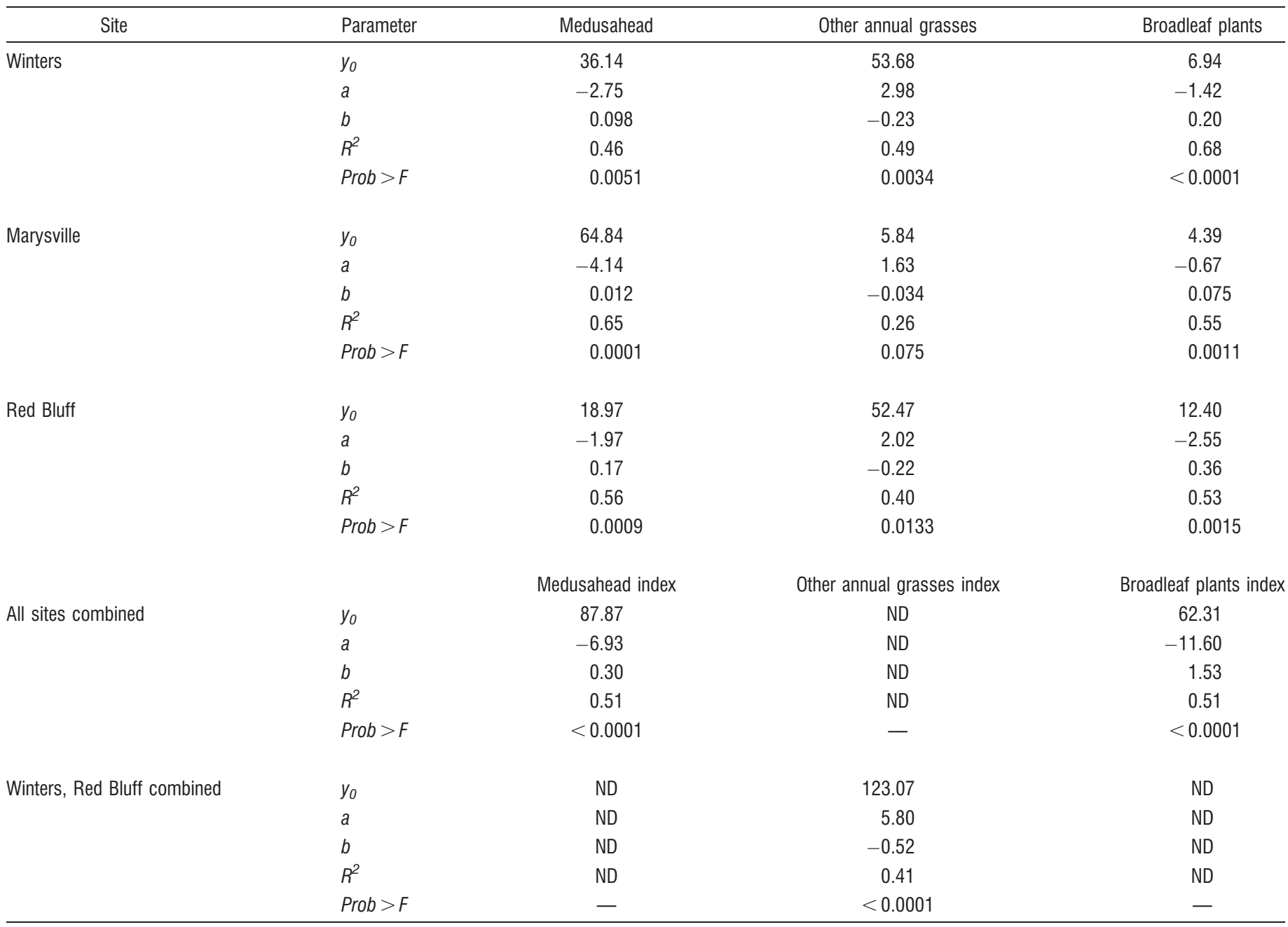

Similarly, we analyzed an index of total cover of other annual grasses combined over Winters and Red Bluff.

\section{RESULTS}

A full list of species recorded in the vegetative surveys is shown in Table 1. Interestingly, species richness was very low within these infested plots, and the vast majority of species present were nonnative. In regression analysis of the dominant vegetative cover components (medusahead, other annual grasses, and broadleaf plants), it was found that all three components responded significantly to rate of aminopyralid at all three sites (Table 2). The only exception was other annual grasses at Marysville, which comprised too low a proportion of the cover to show significant effects. Medusahead cover and broadleaf cover also showed significant rate responses when indexed (expressed as percent cover relative to untreated plots) and combined over all sites. Likewise, other annual grasses showed a strong rate response when indexed and combined for Winters and Red Bluff.

\section{Effects on Medusahead}

Aminopyralid reduced medusahead cover, especially at the highest rates, in all sites (Table 3). Using an index of medusahead control (100 - [\% cover relative to untreated]) to compare control among the sites, we found no differences by site $(P=0.234$ for the rate series of aminopyralid; $P=0.149$ for all treatments). Treatments had a robust and consistent effect across all three sites $(P<0.0001)$, with the high rate of aminopyralid (245 $\left.\mathrm{g} \cdot \mathrm{ha}^{-1} \mathrm{ae}\right)$ producing an overall mean of $89 \% \pm 3$ standard deviation (SD) control (Fig. 1). However, the highest labeled rate for broadcast application of aminopyralid, $123 \mathrm{~g} \cdot \mathrm{ha}^{-1}$ ae $\left(7 \mathrm{oz} \cdot \mathrm{acre}^{-1}\right.$ product), only gave an average of $59 \% \pm 10 \mathrm{SD}$ reduction in cover.

Mean height of medusahead plants tended to be slightly reduced in plots treated with high rates of aminopyralid, but this effect was not usually significant (Table 3 ). The number of 
Table 3. Treatment effects on medusahead at each site. Values followed by different letters indicate differences as determined by the Tukey-Kramer Honestly Significant Difference test. The probability of treatment differences occurring by chance is indicated for each factor ("Prob $>F$ "). N/a indicates not applicable.

\begin{tabular}{|c|c|c|c|c|c|}
\hline \multirow[b]{2}{*}{ Site } & \multicolumn{2}{|c|}{ Treatment } & \multicolumn{3}{|c|}{ Medusahead } \\
\hline & Chemical & Rate $\left(\mathrm{g} \cdot \mathrm{ha}^{-1}\right.$ ae or ai) ${ }^{1}$ & Cover (\%) & Height $(\mathrm{cm})$ & Seeds head ${ }^{-1}$ \\
\hline \multirow[t]{9}{*}{ Winters } & Untreated & $\mathrm{n} / \mathrm{a}$ & $41 \mathrm{a}$ & 45 & $16 a b$ \\
\hline & Aminopyralid & 53 & $25 a b$ & 40 & $15 a b$ \\
\hline & Aminopyralid & 88 & $23 a b$ & 36 & $13 \mathrm{~b}$ \\
\hline & Aminopyralid & 123 & $20 a b$ & 39 & $13 b$ \\
\hline & Aminopyralid & 245 & $4 \mathrm{~b}$ & 38 & $12 \mathrm{~b}$ \\
\hline & Rimsulfuron & 18 & $40 \mathrm{a}$ & 45 & $14 \mathrm{~b}$ \\
\hline & Rimsulfuron & 35 & $35 \mathrm{a}$ & 46 & $17 a b$ \\
\hline & Imazapic & 140 & $5 b$ & 40 & $20 \mathrm{a}$ \\
\hline & Prob $>F$ & - & 0.0007 & 0.0463 & 0.0017 \\
\hline \multirow[t]{9}{*}{ Marysville } & Untreated & $\mathrm{n} / \mathrm{a}$ & $63 \mathrm{a}$ & $63 \mathrm{a}$ & $18 \mathrm{~b}$ \\
\hline & Aminopyralid & 53 & $56 \mathrm{a}$ & $54 a b$ & $18 \mathrm{~b}$ \\
\hline & Aminopyralid & 88 & $50 \mathrm{a}$ & $53 a b$ & $19 \mathrm{~b}$ \\
\hline & Aminopyralid & 123 & $28 a b$ & $49 a b$ & $19 \mathrm{~b}$ \\
\hline & Aminopyralid & 245 & $9 \mathrm{~b}$ & $39 \mathrm{~b}$ & $24 \mathrm{a}$ \\
\hline & Rimsulfuron & 18 & $55 \mathrm{a}$ & $54 a b$ & $18 \mathrm{~b}$ \\
\hline & Rimsulfuron & 35 & $33 a b$ & $54 a b$ & $21 a b$ \\
\hline & Imazapic & 140 & $50 \mathrm{a}$ & $61 \mathrm{a}$ & $24 \mathrm{a}$ \\
\hline & Prob $>F$ & - & 0.0009 & 0.0021 & 0.001 \\
\hline \multirow[t]{9}{*}{ Red Bluff } & Untreated & $\mathrm{n} / \mathrm{a}$ & $26 \mathrm{a}$ & 46 & $19 \mathrm{~b}$ \\
\hline & Aminopyralid & 53 & $11 a b c$ & 44 & 17 bc \\
\hline & Aminopyralid & 88 & $9 \mathrm{bc}$ & 41 & 18 bc \\
\hline & Aminopyralid & 123 & 8 bc & 36 & $17 \mathrm{bc}$ \\
\hline & Aminopyralid & 245 & $3 c$ & 40 & $13 \mathrm{c}$ \\
\hline & Rimsulfuron & 18 & $14 \mathrm{abc}$ & 44 & $22 a b$ \\
\hline & Rimsulfuron & 35 & $15 a b c$ & 43 & $25 \mathrm{a}$ \\
\hline & Imazapic & 140 & $20 a b$ & 48 & $25 \mathrm{a}$ \\
\hline & Prob $>F$ & - & 0.0030 & 0.0501 & $<0.0001$ \\
\hline
\end{tabular}

${ }^{1}$ Aminopyralid and imazapic rates are acid equivalent (ae); rimsulfuron rates are active ingredient (ai).

seeds per head trended higher in imazapic-treated plots but was not consistently different from untreated plots or from the other treatments within each site. Percent filled seeds and germination of filled seeds were not different among treatments within each site, averaging $96 \% \pm 4 \mathrm{SD}, 81 \% \pm 8 \mathrm{SD}$, and $96 \% \pm 3$ SD for filled seeds and $98 \% \pm 3 \mathrm{SD}, 91 \% \pm 5 \mathrm{SD}$, and $94 \% \pm 5$ SD for germination of filled seed at Winters, Marysville, and Red Bluff, respectively. As such, treatment data for these evaluations are not presented.

Rimsulfuron gave inconsistent, often poor, control of medusahead in this trial (3-48\% cover reduction). Imazapic also produced inconsistent results, with control ranging from $21 \%$ and $23 \%$ in Marysville and Red Bluff, respectively, to $88 \%$ in Winters.

\section{Effects on Other Species}

Cover of annual grasses other than medusahead tended to increase following aminopyralid application at all three sites (Table 4). This difference was significant for plots treated with the highest rate of aminopyralid at Winters and Red Bluff. Untreated plots at the Marysville site had only 5\%

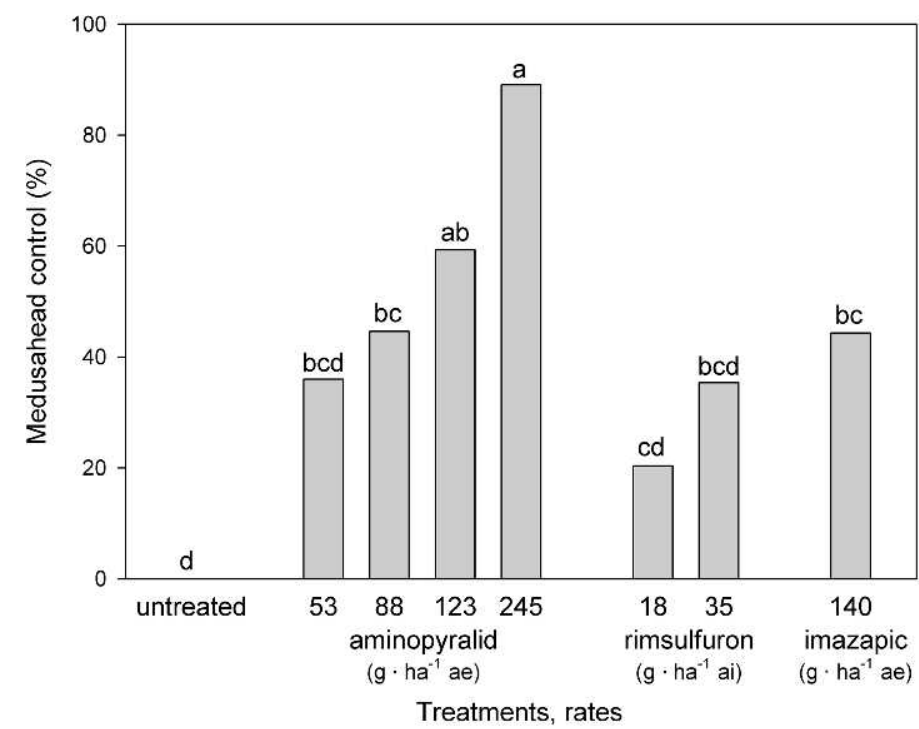

Figure 1. Medusahead control, relative to untreated plots, combined over all three sites. Bars indicated by different letters are different at $\alpha=0.05$ (Tukey-Kramer Honestly Significant Difference test). 
Table 4. Treatment effects on other annual grasses, broadleaves, and biomass at each site. Values followed by different letters indicate differences as determined by the Tukey-Kramer Honestly Significant Difference test. The probability of treatment differences occurring by chance is indicated for each factor ("Prob $>F$ ").

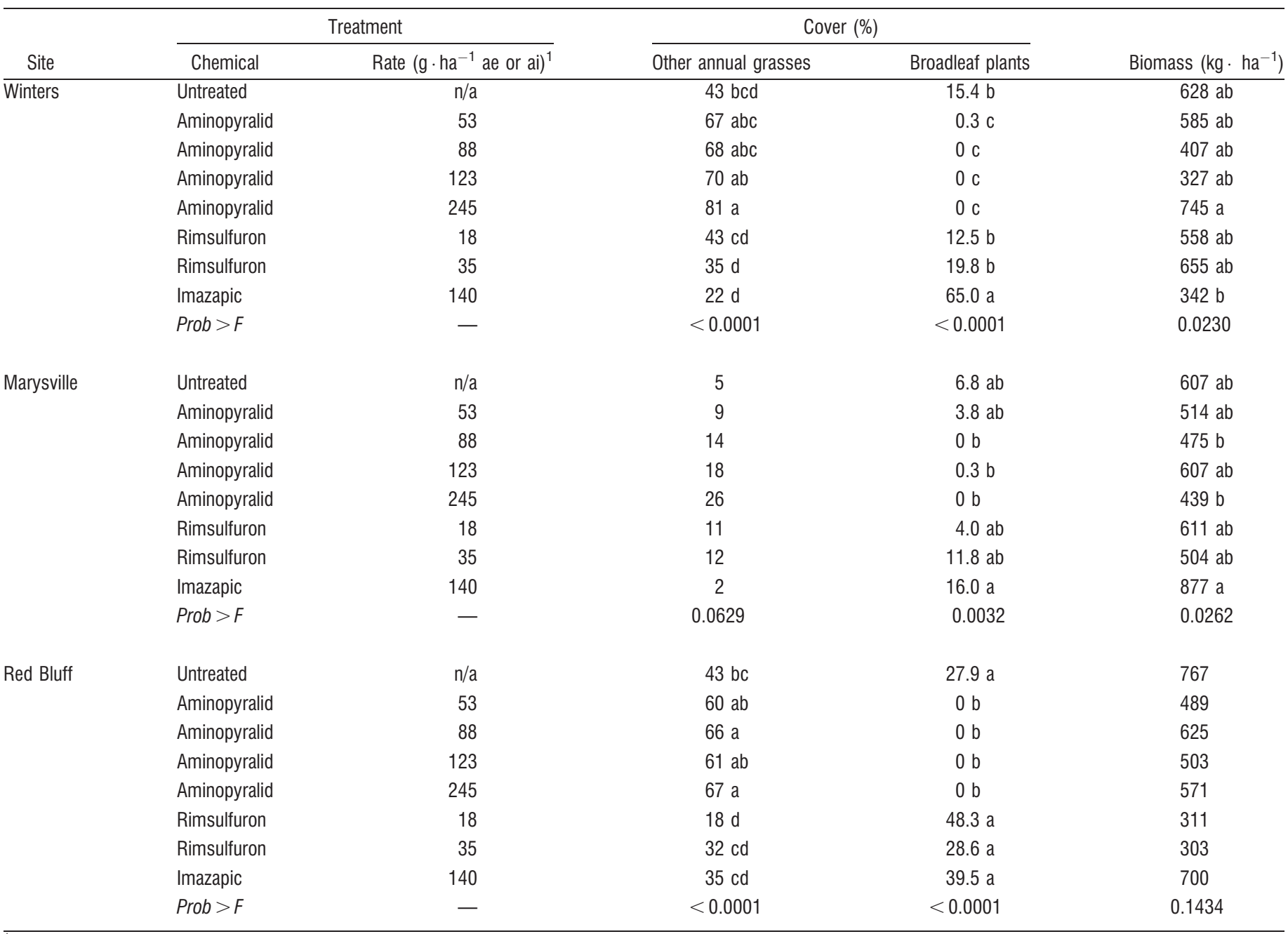

${ }^{1}$ Aminopyralid and imazapic rates are acid equivalent (ae); rimsulfuron rates are active ingredient (ai).

cover of annual grasses other than medusahead; although annual grass cover still tended to increase with aminopyralid treatment at this site, the increase was not statistically significant. Combined data from Winters and Red Bluff likewise showed an increase (52-83\%) in annual grass cover with aminopyralid treatments compared to untreated plots (Fig. 2). In contrast, cover of annual grasses in rimsulfuron and imazapic plots was similar to cover in untreated controls but was significantly lower than in aminopyralid treated plots.

At all three sites, the dominant broadleaf species were members of the Asteraceae (Table 1), a family that is known to be sensitive to aminopyralid (Enloe et al. 2007, 2008; Seefeldt and Conn 2011). In contrast to annual grasses, aminopyralid dramatically reduced, and often eliminated, broadleaf cover at all sites (Table 4). Rimsulfuron treatments had no significant effect on broadleaves, and imazapic treatments resulted in increased broadleaf cover at all three sites, particularly at the Winters site. Imazapic been shown to be weak on many species in the Asteraceae (Shinn and Thill 2002; Kyser et al. 2007), which represented the dominant broadleaf species at all three sites. Total biomass did not show consistent differences among treatments from site to site, though most treatments tended to result in slight reductions in biomass compared to untreated controls.

\section{DISCUSSION}

As an auxinic herbicide, aminopyralid was not previously thought to provide suppression of grasses. However, other recent studies have reported the use of aminopyralid for control of hare barley (H. murinum L. ssp. leporinum [Link] Arcang.; Hulting et al. 2012) and suppression of Japanese brome (B. japonicus Thunb.; Rinella et al. 2010). The results of the current study show that at high rates, and with preemergence application timing, aminopyralid can be an option for suppression of medusahead on California annual rangeland. The effects of aminopyralid in this study were somewhat selective, reducing medusahead cover while increasing cover of other, more desirable annual grasses. This beneficial effect on other grasses is likely due to suppression 


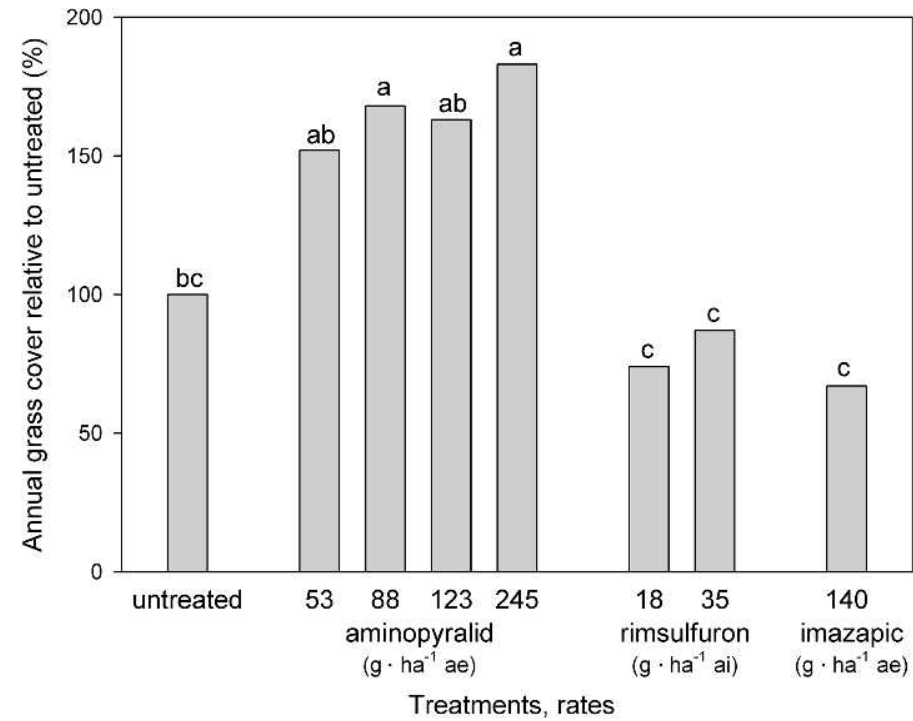

Figure 2. Percent change in annual grasses other than medusahead, relative to untreated plots, combined for Winters and Red Bluff. Bars indicated by different letters are different at $\alpha=0.05$ (Tukey-Kramer Honestly Significant Difference test).

of both medusahead and the dominant weedy Asteraceae species at each site, resulting in enhanced establishment from the extant seedbank of desirable grasses. As a result, biomass did not show large variations among treatments.

It is not readily apparent from our results whether this apparent selectivity represents higher tolerance to aminopyralid by desirable annual grasses, or enhanced exposure of medusahead seedlings to aminopyralid owing to their relatively rapid germination following wetting (Harris 1977). Both factors may play a part. The exact mechanism of selectivity may influence whether aminopyralid can be used to achieve similar results under other climate regimes, e.g., in high-elevation, cold winter areas. It is also reported that, in general, perennial grass species show greater tolerance to preemergent applications of aminopyralid than the weedy winter annual grasses (V. F. Peterson, personal communication, March 2010).

In previous field studies performed in cool, arid, highelevation sites (unpublished data), we demonstrated that rimsulfuron can effectively control medusahead at the maximum labeled rate $\left(70 \mathrm{~g} \cdot \mathrm{ha}^{-1}\right.$ ai). Poor control in the current study may be attributable to two factors: 1) our highest application rate was lower than the maximum labeled rate, based on results from a preliminary greenhouse trial; and 2) compared with cooler areas, rimsulfuron appears to degrade quickly in warm-winter areas like our Central Valley foothill sites, allowing medusahead to germinate and establish toward the end of the season. Others (R. G. Wilson, personal communication, June 2010) have observed similar results at lower rimsulfuron application rates.

Imazapic also produced inconsistent control of medusahead. Although we did not measure the litter layer at the three sites, we hypothesize that this inconsistency is due to variations in thatch density. Previous studies have shown that imazapic ties up in thatch, reducing its activity (Kyser et al. 2007). In contrast, clopyralid, which is closely related to aminopyralid, showed no difference in efficacy on yellow starthistle when applied to soils with and without a thatch layer (DiTomaso et al. 1999b).

\section{IMPLICATIONS}

Our results indicate that high rates of aminopyralid applied in fall, before medusahead emergence, can help to suppress this weed in sites similar to annual grasslands of California. This may be a particularly effective management strategy if a target site is also infested with yellow starthistle or other problematic members of the Asteraceae, which are highly susceptible to aminopyralid. In this study, aminopyralid also provided some selectivity among grasses, resulting in increased cover of more desirable annual forage species such as slender oat (Avena barbata Pott ex Link) and Italian ryegrass (Lolium perenne L. subsp. multiflorum [Lam.] Husnot). However, at the maximum labeled broadcast rate $\left(123 \mathrm{~g} \cdot \mathrm{ha}^{-1}\right.$ ae $\left[7 \mathrm{oz} \cdot \mathrm{acre}^{-1}\right.$ product $\left.]\right)$, aminopyralid provides only partial suppression of medusahead (59\% reduction in cover). Medusahead was effectively controlled $(89 \%$ reduction in cover) with the highest rate tested $\left(245 \mathrm{~g} \cdot \mathrm{ha}^{-1}\right.$ ae $\left[14 \mathrm{oz} \cdot \mathrm{acre}^{-1}\right.$ product] $)$; this rate is labeled for spot applications but is above labeled rates for broadcast treatments.

Although we did not return to the sites to evaluate medusahead populations in the year after treatment, we assume that the effects of partial control were relatively short-lived. In other studies, escaped plants and the residual medusahead seedbank have resulted in rapid reinfestation (e.g., Monaco et al. 2005; Kyser et al. 2008). In addition, following the end of the study, the sites were returned to cattle grazing, a disturbance factor which may also enhance establishment of medusahead. Nevertheless, this treatment may be a useful management tool in situations requiring intensive management, such as small infestations and revegetation projects. There are few other options for selective suppression of medusahead in rangeland, and the degree of suppression demonstrated in this study opens a window for other rangeland rehabilitation efforts. The applicability of aminopyralid for medusahead control will depend on the density and extent of a medusahead infestation, on other undesirable species (e.g., thistles) that may be present on the site, and on the degree of management warranted by intended uses of the site.

\section{ACKNOWLEDGMENTS}

For the Winters site, thanks to Morgan Doran (Cooperative Extension Farm Advisor, Solano, Yolo, and Napa counties), to the Audubon Bobcat Ranch, and to the Lindemann family for allowing access to the site. For the Marysville site, thanks to the Sierra Foothill Research and Extension Center and to Dustin Flavell (Center Superintendent). For the Red Bluff site, thanks to the Gallatin Ranch. And thanks to Carlos Figueroa and Joe Webster, undergraduate research assistants, for processing the samples and performing the germination tests.

\section{LITERATURE CITED}

Bovey, R. W., D. LeTourneau, and L. C. Erickson. 1961. The chemical composition of medusahead and downy brome. Weeds 9:307-311. 
Carrithers, V. F., P. L. Burch, W. N. Kline, R. A. Masters, J. A. Nelson, M. B. Halstvedt, J. L. Troth, AND J. M. Breuninger. 2005. Aminopyralid: a new active ingredient for control of broadleaf invasive and noxious weeds. Abstracts: Weed Science Society of America, 45th Annual Meeting; 7-10 February 2005; Honolulu, HI, USA: Weed Science Society of America. p. 114.

DiTomaso, J. M., G. B. Kyser, M. R. George, M. P. Doran, and E. A. Laca. 2008. Control of medusahead using timely sheep grazing. Invasive Plant Science and Management 1:241-247.

DiTomaso, J. M., G. B. Kyser, And M. S. Hastings. 1999a. Prescribed burning for control of yellow starthistle (Centaurea solstitialis) and enhanced native plant diversity. Weed Science 47:233-242.

Ditomaso, J. M., G. B. Kyser, S. B. Orloff, S. F. Enloe, and G. A. Nader. 1999b. New growth regulator herbicide provides excellent control of yellow starthistle. California Agriculture 53:12-16.

Duncan, C. L., AND J. K. CLARK. 2005. Invasive plants of range and wildlands and their environmental, economic, and societal impacts. Lawrence, KS, USA: Weed Science Society of America. $222 \mathrm{p}$.

Enloe, S. F., G. B. Kyser, S. A. Dewey, V. Peterson, and J. M. DiTomaso. 2008. Russian knapweed (Acroptilon repens) control with low rates of aminopyralid on range and pasture. Invasive Plant Science and Management 1:385-389.

Enloe, S. F., R. G. Lym, R. Wilson, P. Westra, S. Nissen, G. Beck, M. Moechnig, V. Peterson, R. A. Masters, and M. Halstvedt. 2007. Canada thistle (Cirsium arvense) control with aminopyralid in range, pasture, and noncrop areas. Weed Technology 21:890-894.

Ferrell, J. A., J. J. Mullahey, K. A. Langeland, and W. N. Kline. 2006. Control of tropical soda apple (Solanum viarum) with aminopyralid. Weed Technology 20:453-457.

GEORGE, M. R. 1994. Annual rangeland management principles and practices. In S. B. Monsen and S. G. Kitchen [comps.]. Proceedings: Symposium on ecology, management and restoration of intermountain annual rangelands; 18-21 May 1992; Boise, ID, USA. Ogden, UT, USA: USDA Forest Service Intermountain Research Station. General Technical Report INT-313. p. 392-395.

HarRIS, C. A. 1977. Root phenology as a factor of competition among grass seedlings. Journal of Range Management 30:172-177.

HiRonaKA, M. 1961. The relative rate of root development of cheatgrass and medusahead. Journal of Range Management 14:263-267.
Hulting, A. G., J. L. Haavisto, and G. Pirelli. 2012. Biology and management of hare barley in cool-season grass pastures. Proceedings of the 65th Western Society of Weed Science Conference; 12-15 March 2012; Reno, NV, USA. (in press).

Kyser, G. B., J. M. Ditomaso, M. P. Doran, S. B. Orloff, R. G. Wilson, D. L. Lancaster, D. F. LILE, and M. L. PoRATH. 2007. Control of medusahead (Taeniatherum caputmedusae) and other annual grasses with imazapic. Weed Technology 21:65-75.

Kyser, G. B., M. P. Doran, N. K. McDougald, S. B. Orloff, R. N. Vargas, R. G. Wilson, AND J. M. DiTomaso. 2008. Site characteristics determine the success of prescribed burning for medusahead control. Invasive Plant Science and Management 1:376-384.

Monaco, T. A., T. M. Osmond, and S. A. Dewey. 2005. Medusahead control with falland spring-applied herbicides on northern Utah foothills. Weed Technology 19:653-658.

Rinella, M. J., M. R. Haferkamp, R. A. Masters, J. M. Muscha, S. E. Bellows, and L. T. VermelRE. 2010. Growth regulator herbicides prevent invasive annual grass seed production. Invasive Plant Science and Management 3:12-16.

SAS InSTITUTE. 2008. JMP statistics and graphics guide. Version 8.0. Cary, NC, USA: SAS Institute, Inc. $1230 \mathrm{p}$.

Seefeldt, S., and J. Conn. 2011. Control of orange hawkweed (Hieracium aurantiacum) in southern Alaska. Invasive Plant Science and Management 4:87-94.

Sheley, R. L., M. F. Carpinelli, and K. J. Reever Morghan. 2007. Effects of imazapic on target and nontarget vegetation during revegetation. Weed Technology 21:10711081.

ShinN, S. L., AND D. C. Thill. 2002. The response of yellow starthistle (Centaurea solstitialis), annual grasses, and smooth brome (Bromus inermis) to imazapic and picloram. Weed Technology 16:366-370.

Sweet, S. B., G. B. Kyser, And J. M. DiTomaso. 2008. Susceptibility of exotic annual grass seeds to fire. Invasive Plant Science and Management 1:158-167.

University of California, Integrated Pest Management. 2010. UC IPM online. Available at: http://www.ipm.ucdavis.edu/WEATHER/index.html. Accessed 1 December 2010.

USDA-NRCS. 2011. Web soil survey. Available at: http://websoilsurvey.nrcs.usda. gov/app/. Accessed 6 July 2011.

Young, J. A., R. A. Evans, and J. Robison. 1972. Influence of repeated annual burning on a medusahead community. Journal of Range Management 25:372-375. 